\title{
Assessment of Heavy Metal Content of Drain Water with in Cement Production Environment in Port Harcourt, Nigeria
}

\author{
Iyama, William Azuka ${ }^{1}$, Edori, OnisogenSimeon ${ }^{2 *}$, Nwabgara, Victor Uzoma ${ }^{3}$ \\ ${ }^{I}$ Rivers State College of Health Science and ManagementTechnology, Port Harcourt, Nigeria. \\ ${ }^{2}$ Department of Chemistry, Faculty of Natural and Applied Sciences, Ignatius Ajuru University of Education, \\ Rumuolumeni, PMB 5047, Port Harcourt, Rivers State, Nigeria. \\ ${ }^{3}$ Faculty of Engineering, Namibia University of Science andTechnology, Windhoek, Namibia
}

*Corresponding Authors: Edori, OnisogenSimeon, Department of Chemistry, Faculty of Natural and Applied Sciences, Ignatius Ajuru University of Education, Rumuolumeni, PMB 5047, Port Harcourt, Rivers State, Nigeria.

\begin{abstract}
This study was based on the assessment of heavy metal content of drain water within the vicinity of cement factory and other associated activities. Heavy metal concentration analysis was done using the atomic absorption spectrophotometer as described in APHA $3111 \mathrm{~B}$ and ASTM D3651. The present research work deals with the study of seven (7) heavy metals $(\mathrm{Cr}, \mathrm{Mn}, \mathrm{Fe}, \mathrm{Cu}, \mathrm{Zn}, \mathrm{Cd}$, and $\mathrm{Pb}$ ). The result showed ranges of $\mathrm{Cr}(0.25 \pm 0.01-0.29 \pm 0.01, \mathrm{Fe}(<0.01-0.02 \pm 0.00), \mathrm{Mn}(0.34 \pm 0.01-0.39 \pm 0.02), \mathrm{Cu}(0.41 \pm 0.05-$ $0.52 \pm 0.03), \mathrm{Zn}(0.44 \pm 0.04-0.54 \pm 0.04), C d(0.09 \pm 0.03-0.18 \pm 0.04), \mathrm{Pb}(0.01 \pm 0.00-0.02 \pm 0.00)$. There was low concentration of $\mathrm{Fe}$, but $\mathrm{Cu}$ is gradually building up as its concentration is very close to the WHO limits even though below that of FEPA/ FMENV and SON. A one-way ANOVA was used to compare the relationship of the three months (April, May and June) and the three stations (X, Y and Z). Temporal and spatial variation showed result not significant $(p<0.05)$ as $F$-ratio were 0.1224 and 0.0121 respectively. Similarly, $t$-test was used to compare the mean values from the control values $(p \leq 0.05)$. The result showed that for April and June there were statistical significance unlike in May compared to the control station results.The study also revealed that $\mathrm{Cr}, \mathrm{Mn}, \mathrm{Zn}, \mathrm{Cd}$ exceeded the regulatory standards but Pb presence is a potential threat. The potential variation of heavy metals in the study was of the trend, $F e<P b<C d<C r<M n<C u<Z n$. The concentrations of all the heavy metals were larger than their respective control values showing the impact of external factors which must be checked.There should be deliberate attempt to regulate the activities of subsidiary operations within the premises of the cement factory and the associated industries around the area.
\end{abstract}

Keywords: Heavy metal, anthropogenic, Dangote Cement, $\mathrm{Cd}, \mathrm{Zn}, \mathrm{Cr}, \mathrm{Cu}, \mathrm{Mn}$, bioaccumulation, Mining

\section{INTRODUCTION}

The defining factor of heavy metals is the density. Metals of specific densities more than $5 \mathrm{~g} / \mathrm{cm}^{3}$ and have deleterious effect on the living things and the ecosystem are considered as Heavy metals (Järup, 2003). But Singh (2007) posits that any metal considered hazardous may be called heavy metal irrespective of the weight, atomic mass or density. Similarly, any toxic metal may be called heavy metal, irrespective of their atomic mass or density (Singh, 2007). Heavy metals are a part of an illdefined subset of elements that exhibit metallic features and characteristics including the transition metals, some metalloids, lanthanides, and actinides. One source defines heavy metal as one of the common transition metals, such as copper, lead, and zinc. These metals are a cause of environmental pollution from sources such as leaded petrol, industrial effluents, and leaching of metal ions from the soil into lakes and rivers by acid rain (Dictionary of Chemistry, 2000).Similarly, heavy metals are characterized by relatively high density and high relative atomic weight with an atomic number greater than 20, though other meanings of atomic mass exceeding 23 also exist (Koller \& Saleh, 2018).

Even though Heavy metals are natural components of the earth's crust, anthropogenic inputs have drastically affected their geochemical cycles and biochemical balance (Singh, Gautama, Mishra \& Gupta, 2011). Prolonged exposure to certain heavy metals ( $\mathrm{Cd}, \mathrm{Cu}, \mathrm{Pb}, \mathrm{Ni}$, and $\mathrm{Zn}$ ) can lead to 
adverse health effects in humans (Singh, et al., 2011). Molecular understanding of plant metal accumulation has numerous biotechnological implications andalso, the long-term effects of which might not be yet known (Singh, et al., 2011). Any metal (or metalloid) species may be considered a "contaminant" if it occurs where it is unwanted, or in a form or concentration that causes a detrimental human or environmental effect (McIntyre, 2003; Singh, et al., 2011). Mining has both primary and secondary impact in developing countries like Namibia which is one of the most arid country in SubSaharan.Primary impacts are those resulting from the mining activity itself, such as water consumption, scars on the landscape, destruction of flora and fauna, and damage to the social environment. Secondary impacts are those that result from spin offs of the mining activity such as littering, family members flow with small livestock which become an additional impact on flora, the migration of people from other regions to the mining vicinity, money raised from mining but not spent in the region.

All metals are toxic at high concentrations, but excessive levels can be dangerous to the organism(Chronopoulos, Haidouti, Chronopoulou\&Massas, 1997). Bioaccumulation of heavy metals in human bodies is very detrimental because they are toxic and cause multiple damages to organs (Tchounwouet al., 2012). Araujo et al., (2013) supported the outcome of the study of Tchounwouet al., (2012) by stating that; "the presence of heavy metals in the environment, even in moderate concentrations, is detrimental to human health that produces variety of illnesses of the central nervous system $(\mathrm{Mg}, \mathrm{Hg}, \mathrm{Pb} \mathrm{As})$, the kidneys or liver $(\mathrm{Hg}, \mathrm{Pb}, \mathrm{Cd}, \mathrm{Cu})$ and skin, bones, or teeth $(\mathrm{Ni}, \mathrm{Cd}, \mathrm{Cu}$, Cr)".

According to Singh, Labana, Pandey, Budhirajaand Jain (2003) heavy metal contaminations of land resources continue to be the focus of numerous environmental studies and attract a great deal of attention worldwide. This is attributed to non- biodegradability and persistence of heavy metals in soils. Metals cause environmental pollution from sources such as leaded petrol, industrial effluents, and leaching of metal ions from the soil into lakes and rivers by acid rain (A dictionary of Chemistry, 2000).Lead ( $\mathrm{Pb}), \mathrm{Zn}, \mathrm{Cu}, \mathrm{As}, \mathrm{Cd}, \mathrm{Cr}, \mathrm{Ni}$ and $\mathrm{Hg}$ remain the commonest heavy metals observed in wastewater (Ahmed \&Ahmaruzzaman, 2016; Akpor\&Muchie, 2010). Any metal (or metalloid) species may be considered a "contaminant" if it occurs where it is unwanted, or in a form or concentration that causes a detrimental human or environmental effect (Singh et al., 2011). Heavy metals are both precious noble elements and also toxic to man and the environment (Rao\&Reddi, 2000; Duruibe, Ogwuegbu, \&Egwurugwu, 2007). Similarly, heavy metals are highly persistent, toxic in trace amounts, and can potentially induce severe oxidative stress in aquatic organisms (Singh \&Kalamdhad, 2011).

Chronic and sub-chronic effects may occur due to exposure to heavy metals leading to complications such as shortness of breath, neurotoxic, mutagenic and teratogenic effects depending on the specific heavy metal (Chowdhury, Mazumder, Al-Attas\& Husain, 2016;Mahdavi, Amin, Mahvi, Pourzamani, \& Ebrahimi, 2018). Typical cases are $\mathrm{Cu}, \mathrm{Pb}$, and $\mathrm{Cd}$ linked to upper gastrointestinal cancer, which is responsible for about twenty-five percent of all cancer-related deaths in the world (Türkdoğan, Kilicel, Kara, Tuncer, \&Uygan, 2003;Njuguna et al., 2019). Heavy metals are not biodegradable when they accumulate in living organisms. They exhibit carcinogenic properties thus causing various diseases and disorders (Singh etal., 2011). $\mathrm{Pb}, \mathrm{Cd}$ and $\mathrm{Cu}$ are heavy metals that have been associated with adverse health effects, ranging from irritation of the respiratory system and premature death across people of all ages. Children are more susceptible to ill-effects of heavy metal contamination because of their high body metabolism (Xiang et al., 2019).Contaminants in aquatic systems which includes heavy metals, stimulate the production of reactive oxygen species (ROS) that can damage fishes and other aquatic organisms (Singh et al., 2011).Research has shown that Heavy metals are one of the most widespread contaminants in the environment as their presence can lead to environmental pollution from different sources including industrial effluents, atmospheric deposition and leaching of metal ions from the soil into water bodies by acid rain (Zorpas, Vassilis,Loizidou\&Grigoropoulou, 2002;Cai, Mob, Wu, Zenga\&Katsoyiannis, 2007; Neklyudov, Fedotov\&Ivankin, 2008). According to Singh and Kalamdhad (2011), heavy metals are released into aquatic systems and get bound to particulate matter which now settles into sediments. Heavy metals have deleterious effects and become toxic when they are not metabolized by the body accumulating in soft tissues (Sobha, Poornima, Harini, \&Veeraiah, 2007). Chronic level ingestion of toxic metals 
has undesirable effects on man and the associated harmful impacts becomeperceptible only after prolonged period of years (Khan, Cao, Zheng, Huang\&Zhu, 2008).Periodically monitoring sewage effluents for heavy metal contamination levels as to determine the quality of waste water being discharged to the environment especially to poorly constructed drains to avoid groundwater contamination and pollutions very necessary. No deliberate attempts have been made around this study area (old Eagle Cement road and drains) in Port Harcourt, Nigeria except those of Iyama and Edori (2019) to determine the levels of heavy metals in the sewage effluent emanating from the nearby abandoned dumpsite of the Rivers State Government, Nigeria. The aim of this study was to therefore ascertain the levels of $\mathrm{Cr}, \mathrm{Fe}, \mathrm{Mn}, \mathrm{Cu}, \mathrm{Zn}, \mathrm{Cd}$ and $\mathrm{Pb}$ in the drains and compared with control stations from adjacent drains from the Aker Road end.

Available research shows that heavy metals pollution in soil and water has a lot of negative impacts hence is of great concern to agricultural production, public and environmental health (Fergusson, 1990; Msaky\&Calvet, 1990; Ma,Traina, Logan \& Ryan,1994; Goyer, 1997). Soil pollution is mainly due to disposal of industrial and urban wastes including the use of agrochemicals (Buchauer, 1973; McBride, 2003; Demirezen\& Aksoy, 2006), while water pollution is primarily caused by industrial wastes, sewage disposal, petroleum contamination, and agricultural drainage water, surface and ground (Santos, Silva-Filho, Schaefer, Albuquerque-Filho \& Campos, 2005;Midrar-Ul-Haq, Khattak, Puno, Saif\&Memon, 2005; Tariq, Ali \&Shah, 2006). Many growing areas in developing countries are vulnerable to air pollution due to the fact that heavy metals containing aerosols are normally deposited on soil surfaces and plants (Voutsa, Grimanis\& Samara, 1996)

Most drainage found at the suburbs of Port Harcourt city shows poor construction and so infiltration and leaching of contaminants are likely suspected, which is a serious threat to ground water. Port Harcourt does not have a central drainage and town water supply and this poses great danger as each home dig borehole due to government failure in that regard. Along the stretch of the road are seen water tanks showing that their boreholes are not far from the government drainage. Therefore, this study was able to determine the levels of these heavy metals comparing them with permissible standards of WHO and the Nigerian Federal Ministry of Environment.

\section{MATERIALS AND MethodS}

\subsection{Water Sample Collection}

Water samples of $250 \mathrm{~mL}$ each were collected from the drains using pre-cleaned plastic bottles. For every study station three (3) adjacent surface water samples at a depth of $10-15 \mathrm{~cm}$ depending on the volume of water in the drain are taken and then composited from stations $\mathrm{X}, \mathrm{Y}, \mathrm{Z}$ for the months of April, May and June, 2020. These samples were labeled and transported to the research laboratory at the Institute of Pollution Studies, Rivers State University, Port Harcourt for proper analysis. After filtering, $2.5 \mathrm{~mL}$ of concentrated nitric acid $\left(\mathrm{HNO}_{3}\right)$ was added to the samples to lower the $\mathrm{pH}$ (to $\left.<2\right)$ to prevent precipitation and any microbial activity during storage (Jabeen, Aslam, \& Salman, (2018). To minimize any chemical alteration and purity, drain samples were stored at $4{ }^{\circ} \mathrm{C}$ before analysis (Noreen, Shahid, Iqbal, \& Nisar, 2017). Acid digestion of the samples was done by adding $5 \mathrm{~mL}$ of concentrated nitric acid to a well-mixed $50 \mathrm{~mL}$ sample in a beaker and covered with a ribbed watch glass. To facilitate boiling, glass beads were added and was evaporated on a hot plate up to $10-20 \mathrm{~mL}$ until a clear solution was obtained. The sample was then filtered and transferred in a $100 \mathrm{~mL}$ volumetric flask and filled to the mark using distilled water.

Heavy metal concentration analysis was done using the atomic absorption spectrophotometer as described in APHA 3111B and ASTM D3651. This entailed direct aspiration of the samples into an air/ acetylene flame which was generated by a hollow cathode lamp (light source) at a specific wavelength though peculiar to the metal under consideration and hence programmed. For quality control measures, every metal under study blanks were run and then used for calibration before being aspirated. Finally, concentrations at specific absorbance displayed on the data system monitor and ready for printing (detection limit was set for less than $0.001 \mathrm{mg} / \mathrm{l}$ ).

\subsection{Study Area}

This study was conducted in Port Harcourt and Obio-Akpor local government areas of Rivers State, Nigeria. Port Harcourt is known as port town and capital of Rivers State, Niger Delta, 
Southern Nigeria. It lies along the Bonny River (eastern distributary of the Niger River) 41 miles $(66 \mathrm{~km})$ upstream from the Gulf of Guinea. Port Harcourt was founded in 1912 in an area traditionally occupied by the Ijo (Ijaw), Okrikans, and Ikwere people. The sampling stations were selected based on area features especially sites close to and affected by different human activities such as nearness to the Dangote cement factory as X, the abandoned Waste Dumpsite as Y, and a popular Bar close to the junction where the Police Station is as Z. The study location is within the Rumuolumeni community but bound by the Dangote Group, the Ignatius Ajuru University of Education and a prominent abandoned waste dump of the Rivers State Government. Also, around the study area is the Police station. The geographical location is shown in Table 1 using the geographic positioning system (GPS) from Techno android phone.

Table1. Sampling Locations and Description

\begin{tabular}{|l|l|l|}
\hline Item & Study Location & Description \\
\hline 1. & $\mathrm{X}\left(4^{\circ} 47^{\prime} 53^{\prime \prime} \mathrm{N} \& 6^{\circ} 56^{\prime} 36^{\prime \prime} \mathrm{E}\right)$ & Point adjacent the cement factory/ Gas plant \\
\hline 2. & $\mathrm{Y}\left(4^{\circ} 48^{\prime} 23^{\prime \prime} \mathrm{N} \& 6^{\circ} 56^{\prime} 36^{\prime} \mathrm{E}\right)$ & Point adjacent the Abandoned Dumpsite \\
\hline 3. & $\mathrm{Z}\left(4^{\circ} 48^{\prime} 42^{\prime \prime} \mathrm{N} \& 6^{\circ} 56^{\prime} 35^{\prime \prime} \mathrm{E}\right)$ & $\begin{array}{l}\text { Point adjacent the Bar and closer to the Iwofe Road } \\
\text { junction/ Police Station }\end{array}$ \\
\hline
\end{tabular}

The control stations recorded latitudes and longitudes of $\mathrm{X}\left(4^{\circ} 48^{\prime} 6^{\prime}\right.$ ' $\mathrm{N}$ and $\left.6^{\circ} 56^{\prime} 36^{\prime \prime} \mathrm{E}\right), \mathrm{Y}$ $\left(4^{\circ} 48^{\prime} 15^{\prime \prime} \mathrm{N}\right.$ and $\left.6^{\circ} 56^{\prime} 16^{\prime \prime} \mathrm{E}\right)$ and $\mathrm{Z}\left(4^{\circ} 48^{\prime} 47^{\prime \prime} \mathrm{N}\right.$ and $\left.6^{\circ} 56^{\prime} 44^{\prime \prime} \mathrm{E}\right)$

\subsection{Research and Sampling Designs}

The pure experimental and longitudinal survey designs were adopted for the study. This study adopted the probability cluster sampling technique.

\subsection{Statistical Analysis}

The mean, standard deviation, one-way ANOVA and the t-test were used to determine the existing relationships within the study stations and between the mean values and control at $95 \%$ confidence level $(\mathrm{p} \leq 0.05)$. Similarly, line graphs and histograms were used to illustrate existing trends.

Table2. Heavy Metal Content of the Eagle Cement Road Water Drains (April, 2020)

\begin{tabular}{|l|l|l|l|l|}
\hline \multirow{2}{*}{$\begin{array}{l}\text { Parameters } \\
(\mathrm{mg} / \mathrm{l})\end{array}$} & & Study Stations & & \multirow{2}{*}{ Control Station } \\
\cline { 2 - 4 } & \multicolumn{1}{|c|}{$\mathrm{X}$} & $\mathrm{Y}$ & $\mathrm{Z}$ & \\
\hline $\mathrm{Cr}$ & $0.33 \pm 0.03$ & $0.30 \pm 0.00$ & $0.25 \pm 0.03$ & $0.03 \pm 0.01$ \\
\hline $\mathrm{Fe}$ & $0.01 \pm 0.00$ & $0.01 \pm 0.00$ & $0.01 \pm 0.00$ & $0.01 \pm 0.00$ \\
\hline $\mathrm{Mn}$ & $0.33 \pm 0.04$ & $0.40 \pm 0.01$ & $0.45 \pm 0.04$ & $0.01 \pm 0.01$ \\
\hline $\mathrm{Cu}$ & $0.54 \pm 0.01$ & $0.55 \pm 0.02$ & $0.47 \pm 0.04$ & $0.02 \pm 0.01$ \\
\hline $\mathrm{Zn}$ & $0.45 \pm 0.06$ & $0.56 \pm 0.01$ & $0.60 \pm 0.04$ & $0.15 \pm 0.02$ \\
\hline $\mathrm{Cd}$ & $0.20 \pm 0.01$ & $0.18 \pm 0.00$ & $0.15 \pm 0.02$ & $0.02 \pm 0.02$ \\
\hline $\mathrm{Pb}$ & $0.02 \pm 0.01$ & $0.01 \pm 0.00$ & $0.01 \pm 0.00$ & $<0.01$ \\
\hline
\end{tabular}

Table3. Heavy Metal Content of the Eagle Cement Road Water Drains (May, 2020)

\begin{tabular}{|l|l|l|l|l|}
\hline \multirow{2}{*}{ Parameters (mg/l) } & & Study Stations & & \multirow{2}{*}{ Control Station } \\
\cline { 2 - 4 } & \multicolumn{1}{|c|}{$\mathrm{X}$} & $\mathrm{Y}$ & $\mathrm{Z}$ & \\
\hline $\mathrm{Cr}$ & $0.34 \pm 0.04$ & $0.28 \pm 0.01$ & $0.26 \pm 0.02$ & $0.026 \pm 0.01$ \\
\hline $\mathrm{Fe}$ & $0.02 \pm 0.00$ & $0.01 \pm 0.01$ & $0.02 \pm 0.00$ & $0.010 \pm 0.01$ \\
\hline $\mathrm{Mn}$ & $0.35 \pm 0.01$ & $0.36 \pm 0.00$ & $0.38 \pm 0.01$ & $0.010 \pm 0.01$ \\
\hline $\mathrm{Cu}$ & $0.50 \pm 0.00$ & $0.54 \pm 0.03$ & $0.47 \pm 0.02$ & $0.010 \pm 0.01$ \\
\hline $\mathrm{Zn}$ & $0.44 \pm 0.03$ & $0.50 \pm 0.01$ & $0.50 \pm 0.01$ & $0.150 \pm 0.01$ \\
\hline $\mathrm{Cd}$ & $0.12 \pm 0.00$ & $0.10 \pm 0.01$ & $0.14 \pm 0.01$ & $0.014 \pm 0.00$ \\
\hline $\mathrm{Pb}$ & $0.01 \pm 0.00$ & $0.01 \pm 0.00$ & $0.01 \pm 0.00$ & $<0.010$ \\
\hline
\end{tabular}

Table4. Heavy Metal Content of the Eagle Cement Road Water Drains (June, 2020)

\begin{tabular}{|l|l|l|l|l|}
\hline \multirow{2}{*}{ Parameters $(\mathrm{mg} / \mathrm{l})$} & & Study Stations & & \multirow{2}{*}{ Control Station } \\
\cline { 2 - 5 } & \multicolumn{1}{|c|}{$\mathrm{X}$} & \multicolumn{1}{|c|}{$\mathrm{Y}$} & $\mathrm{Z}$ & \\
\hline $\mathrm{Cr}$ & $0.30 \pm 0.02$ & $0.26 \pm 0.01$ & $0.25 \pm 0.01$ & $0.025 \pm 0.01$ \\
\hline $\mathrm{Fe}$ & $<0.01$ & $<0.01$ & $<0.01$ & $<0.01$ \\
\hline
\end{tabular}


Assessment of Heavy Metal Content of Drain Water with in Cement Production Environment in Port Harcourt, Nigeria

\begin{tabular}{|l|l|l|l|l|}
\hline $\mathrm{Mn}$ & $0.33 \pm 0.01$ & $0.35 \pm 0.01$ & $0.35 \pm 0.01$ & $<0.01$ \\
\hline $\mathrm{Cu}$ & $0.32 \pm 0.06$ & $0.50 \pm 0.06$ & $0.42 \pm 0.01$ & $<0.01$ \\
\hline $\mathrm{Zn}$ & $0.40 \pm 0.03$ & $0.45 \pm 0.01$ & $0.46 \pm 0.01$ & $0.140 \pm 0.01$ \\
\hline $\mathrm{Cd}$ & $0.10 \pm 0.01$ & $0.08 \pm 0.01$ & $0.10 \pm 0.01$ & $0.010 \pm 0.01$ \\
\hline $\mathrm{Pb}$ & $0.01 \pm 0.00$ & $0.01 \pm 0.00$ & $0.01 \pm 0.00$ & $0.001 \pm 0.00$ \\
\hline
\end{tabular}

Table5. Spatial Mean Concentration forHeavy Metals in the Water Drains

\begin{tabular}{|c|c|c|c|c|c|}
\hline \multirow{2}{*}{$\begin{array}{l}\text { Parameters } \\
(\mathrm{mg} / \mathrm{l})\end{array}$} & \multicolumn{3}{|c|}{ Study Stations } & \multirow[t]{2}{*}{ Control } & \multirow{2}{*}{$\begin{array}{l}\text { Standard } \\
\text { Values }\end{array}$} \\
\hline & $\mathrm{X}$ & $\mathrm{Y}$ & $\mathrm{Z}$ & & \\
\hline $\mathrm{Cr}$ & $0.32 \pm 0.02$ & $0.26 \pm 0.00$ & $0.25 \pm 0.02$ & 0.03 & 0.025 \\
\hline $\mathrm{Fe}$ & $0.01 \pm 0.00$ & $0.01 \pm 0.00$ & $0.01 \pm 0.00$ & 0.01 & $<0.01$ \\
\hline $\mathrm{Mn}$ & $0.34 \pm 0.02$ & $0.37 \pm 0.00$ & $0.39 \pm 0.01$ & 0.01 & $<0.01$ \\
\hline $\mathrm{Cu}$ & $0.45 \pm 0.02$ & $0.53 \pm 0.03$ & $0.45 \pm 0.02$ & 0.01 & $<0.01$ \\
\hline $\mathrm{Zn}$ & $0.43 \pm 0.03$ & $0.50 \pm 0.01$ & $0.52 \pm 0.02$ & 0.15 & 0.140 \\
\hline $\mathrm{Cd}$ & $0.14 \pm 0.01$ & $0.12 \pm 0.01$ & $0.13 \pm 0.01$ & 0.01 & 0.010 \\
\hline $\mathrm{Pb}$ & $0.01 \pm 0.00$ & $0.01 \pm 0.00$ & $0.01 \pm 0.00$ & 0.01 & 0.001 \\
\hline
\end{tabular}

Table6. Temporal Mean Concentration for Heavy Metals in the Water Drains

\begin{tabular}{|l|l|l|l|l|l|}
\hline \multirow{2}{*}{$\begin{array}{l}\text { Parameters } \\
(\mathrm{mg} / \mathrm{l})\end{array}$} & \multicolumn{2}{|l|}{ Study Stations } & \multirow{2}{*}{ Control } & \multirow{2}{*}{ Standard Values } \\
\cline { 2 - 4 } & \multicolumn{1}{|c|}{ April } & May & June & & \\
\hline $\mathrm{Cr}$ & $0.29 \pm 0.01$ & $0.29 \pm 0.01$ & $0.27 \pm 0.01$ & 0.28 & 0.025 \\
\hline $\mathrm{Fe}$ & $0.01 \pm 0.00$ & $0.02 \pm 0.00$ & $<0.01 \pm 0.01$ & & $<0.01$ \\
\hline $\mathrm{Mn}$ & $0.39 \pm 0.02$ & $0.36 \pm 0.00$ & $0.34 \pm 0.01$ & 0.42 & $<0.01$ \\
\hline $\mathrm{Cu}$ & $0.52 \pm 0.03$ & $0.50 \pm 0.01$ & $0.41 \pm 0.05$ & 0.48 & $<0.01$ \\
\hline $\mathrm{Zn}$ & $0.54 \pm 0.04$ & $0.48 \pm 0.01$ & $0.44 \pm 0.04$ & 0.49 & 0.140 \\
\hline $\mathrm{Cd}$ & $0.18 \pm 0.04$ & $0.12 \pm 0.01$ & $0.09 \pm 0.03$ & 0.13 & 0.010 \\
\hline $\mathrm{Pb}$ & $0.01 \pm 0.00$ & $0.01 \pm 0.00$ & $0.01 \pm 0.00$ & 0.01 & 0.001 \\
\hline
\end{tabular}

\section{RESULT AND DISCUSSION}

The results of the heavy metals in April, May and June for the different stations of $\mathrm{X}, \mathrm{Y}$ and $\mathrm{Z}$ are shown in Tables 2, 3 and 4 whereas Tables 5 and 6 shows mean spatial and temporal trends for the heavy metals respectively. The mean concentrations of $\mathrm{Cr}(\mathrm{mg} / \mathrm{l})$ in the study stations of $\mathrm{X}, \mathrm{Y}$ and $\mathrm{Z}$ for the months of April, May and June respectively were $0.33 \pm 0.03,0.30 \pm 0.00,0.25 \pm 0.03 ; 0.34 \pm 0.04$, $0.28 \pm 0.01,0.26 \pm 0.02 ; 0.30 \pm 0.02,0.26 \pm 0.01$ and $0.25 \pm 0.01$. The months of April, May and June recorded controls values of $0.03,0.01$ and $<0.01$ respectively. The range of $\mathrm{Cr}$ in the study was $0.25 \pm 0.01-0.34 \mathrm{mg} / \mathrm{l}$. The concentration of $\mathrm{Cr}$ in the study station was higher than those of the control showing anthropogenic inputs of the suspected sites and activities. These values were slightly higher than the permissible limits of $0.05 \mathrm{mg} / \mathrm{l}$ (WHO, 2006; SON, 2002). These values are similar to those of earlier research by Iyama and Edori (2019) on dumpsites in Port Harcourt and Javed and Usmani (2013) on the assessment of heavy metal $(\mathrm{Cu}, \mathrm{Ni}, \mathrm{Fe}, \mathrm{Co}, \mathrm{Mn}, \mathrm{Cr}, \mathrm{Zn})$ pollution in effluent dominated rivulet water. These levels are due to both atmospheric and anthropogenic activities of man but are quite lower than those recorded by Ramesh and Damodhram (2016) on industrial wastewaters. In all the study sites $\mathrm{X}, \mathrm{Y}$ and $\mathrm{Z}, \mathrm{Cr}$ was above the maximum acceptable limit for Chromium as per IS: 10500 is $0.05 \mathrm{mg} / \mathrm{l}$ and maximum acceptable limit as per World Health Organization is $0.05 \mathrm{mg} / \mathrm{l}$ (Raju, Prasad, Varalakshmi \& Reddy, 2014). The concentrations of $\mathrm{Cr}$ were higher in this study than those obtained at ranges from 0.002 to $0.042 \mathrm{mg} / \mathrm{l}$ which is within the permissible limit of $0.05 \mathrm{mg} / \mathrm{l}$ for SON (2002) for similar terrain in the Niger Delta, Nigeria (Imasuen\&Egai, 2013). The concentration of $\mathrm{Cr}$ was highest in May and at the point closer to the cement factory signifying some inputs of activities around it. The least values were recorded at the Z-station close to junction where no serious anthropogenic activities exist except pedestrian and vehicular movements. Pollution of water bodies has become a nuisance today due to poor waste wastewater management due to extensive industrialization, population explosion and rapid development(Bhattacharya \&Bolaji, 2010). This decreases the potable potentials of water and increases the cost of treatment (Terrumun\& Oliver, 2015).

People can be exposed to chromium $(\mathrm{Cr})$ through breathing, eating or drinking and through skin contact with chromium or chromium compounds. The level of chromium in air and water is generally 
low. In drinking water the level of chromium is usually low as well, but contaminated well water may contain the dangerous chromium(IV); hexavalent chromium. This metal falls into one of the eight (8) heavy metals often referred to as RCRA (Resource Recovery and Conservation Act) 8 metals. This is due to their extreme toxicity even at low concentration. Other health implications include skin rashes, upset stomachs and ulcers, respiratory problems, weakened immune systems, kidney and liver damage, alteration of genetic material, lung cancer and even lethal.Through coal combustion chromium will also end up in air and through waste disposal chromium will end up in soils. Chromium VI is the most dangerous form of chromium and may cause health problems including: allergic reactions, skin rash, nose irritations and nosebleed, ulcers, weakened immune system, genetic material alteration, kidney and liver damage, and may even go as far as death of the individual. The concentrations of $\mathrm{Fe}(\mathrm{mg} / \mathrm{l})$ in the study stations of $\mathrm{X}, \mathrm{Y}$ and $\mathrm{Z}$ for the months of April, May and June respectively were $0.01 \pm 0.00,0.01 \pm 0.00,0.01 \pm 0.01 ; 0.02 \pm 0.01,0.01 \pm 0.01,0.02 \pm 0.00 ;$ all $<0.01$. The months of April, May and June recorded controls values of 0.01, 0.01 and $<0.01$ respectively. The range of $\mathrm{Fe}$ concentration found in the study stations on both spatial and temporal dimensions was $<0.01-0.02 \pm 0.00$. The concentration of Fe in the study station was higher than those of the control showing anthropogenic inputs of the suspected sites and activities. This range is an indication of concentrations far below permissible limits by regulatory standards (WHO, 2006; FEPA, 1991; SON, 2002). This was similar to those observed at the Ekerikana water body whose range was $<0.000$ $0.010 \mathrm{mg} / \mathrm{l}$ (Iyama, Eugene-Nwala\&Igoni, 2017). Iron (Fe) concentration was also less than the limit of $5 \mathrm{mg} / \mathrm{l}$ required for irrigation waters (Kar, Sur, Mandal, Saha\&Kole, 2008). This does not agree with those observed in similar ecosystem for dumpsites in Port Harcourt of range 0.05-0.294 (Iyama\&Edori, 2019). Imasuen and Egai (2013) recorded higher concentrations of $\mathrm{Fe}(0.01$ $0.68 \mathrm{mg} / \mathrm{l})$. Similarly, a range of $0.3 \mathrm{mg} / \mathrm{l}-4.8 \mathrm{mg} / \mathrm{l}$ was recorded for waste water by Ramesh and Damodhram (2016) for heavy metals in wastewater.Higher concentration range was also observed for wastewater in similar research (Adesina, Ogunyebi, Fingesi\&Oludoye, 2018). The result in this study is a clear indication of poor $\mathrm{Fe}$ concentration from both the drains from the cement factory and that of the abandoned waste dump. This also means that no Fe metal scraps around the study sites as to impact Fe contamination. Research has shown that the excess of iron in water imparts taste and it also promotes bacterial growth which fastens rusting process of all the ferrous metals that come in contact with the water (Chukwu, Mustapha \& Abdul Gafar, 2008;Rajappa, Manjappa\&Puttaiah, 2010; Bhaskar, Kumar \&Nagendrappa, 2010). According to Imasuen and Egai (2013), iron (Fe) can be derived from marshy and acidic soil environment to which this study location belongs.

The concentrations of $\mathrm{Mn}(\mathrm{mg} / \mathrm{l})$ in the study stations of $\mathrm{X}, \mathrm{Y}$ and $\mathrm{Z}$ for the months of April, May and June respectively were $0.33 \pm 0.04,0.40 \pm 0.01,0.45 \pm 0.04 ; 0.35 \pm 0.01,0.36 \pm 0.00,0.38 \pm 0.01 ; 0.33 \pm 0.01$, $0.35 \pm 0.01$ and $0.35 \pm 0.01$. The months of April, May and June recorded controls values of $0.01,0.01$ and $<0.01$ respectively. The observed range for Mn was $0.34 \pm 0.01-0.39 \pm 0.02$. This was above the permissible limits of $0.1 \mathrm{mg} / \mathrm{l}$ (WHO, 2006; FEPA, 1991) and SON (2002) of 0.05mg/l for water. The concentration of $\mathrm{Mn}$ in the study station was higher than those of the control showing anthropogenic inputs of the suspected sites and activities. The result was found to be higher than those earlier recorded in similar terrain (Imasuen\&Egai (2013). This is a clear indication of Mn contamination which is from anthropogenic imputs. Heavy and trace metals are of immense significance in water as living organisms require varying amounts of some of these metals including Mn as micronutrients for proper growth(Adesina et al.,2018). This was also higher than those recorded for the Ekerikana channel in the Niger Delta, Nigeria (Iyama, Eugene-Nwala\&Igoni, 2017). The analysis of surface waters for $\mathrm{Mn}$ revealed that all the samples have very low concentrations and are suitable for irrigation (Bhaskar et al., 2010). With sufficient surface water infiltration, soil contaminants such as heavy metals can infiltrate into underlying groundwater. The effects of heavy metals on groundwater are different for different types of soils (Zenglu, 1992). The accumulation of metals in wastewater depends on certain factors like way of life and awareness of the impact on the environment through the careless disposal of wastes (Bhattacharya \&Bolaji, 2010). Heavy metals in rivulet water samples for Mn was averagely $0.21 \mathrm{mg} / \mathrm{l}$ which was within similar range for this study though little lower (Javed\&Usmani, 2013).

The concentrations of $\mathrm{Cu}(\mathrm{mg} / \mathrm{l})$ in the study stations of $\mathrm{X}, \mathrm{Y}$ and $\mathrm{Z}$ for the months of April, May and June respectively were $0.53 \pm 0.01,0.55 \pm 0.02,0.47 \pm 0.04 ; 0.50 \pm 0.00,0.54 \pm 0.03,0.47 \pm 0.02 ; 0.32 \pm 0.06$, $0.50 \pm 0.06$ and $0.42 \pm 0.01$. The months of April, May and June recorded controls values of $0.02,0.01$ 
and $<0.01$ respectively. The concentration of $\mathrm{Cu}$ in the study station was higher than those of the control showing anthropogenic inputs of the suspected sites and activities. The observed range for $\mathrm{Cu}$ was $0.41 \pm 0.05-0.52 \pm 0.03$. This was below the permissible limits of $1.0-1.5 \mathrm{mg} / \mathrm{l}$ (FEPA, 1991; SON, 2002) and WHO (2006) of $0.5 \mathrm{mg} / \mathrm{l}$ for drinking water. The concentration of $\mathrm{Cu}$ observed in this study was of lower upper limit than earlier work by Edoriet al. (2016)for heavy metals and physicochemical parameter of selected borehole water from Umuechem, Etche Local government Area, Rivers state, Nigeria (range of $0.239-1.304 \mathrm{mg} / \mathrm{l}$ ) but was higher than those recorded by Iyama and Edori (2019) on the chemical and gross organic pollutant levels in Port Harcourt dumpsites. This was same byImasuen and Egai (2013) for similar water bodies. Javedand Usmani (2013) recorded an average of $0.86 \pm 0.01$ $\mathrm{mg} / \mathrm{l}$ which was also slightly higher than those of this study. This amount so recorded showed contamination by $\mathrm{Cu}$ metal. Similarly many water bodies which lie in vicinity of population have been polluted by effluents released by industries, factories, power stations, domestic waste which impairs the quality of water (Javed\&Usmani, 2013). This is most likely result from indiscriminate dumping of waste materials and the soil content. Copper is essential for good health. However, exposure to higher doses can be harmful. Copper $(\mathrm{Cu})$ toxicity in natural water resulting from pollutants and contaminants may affect gills and necrotic changes in the liver and kidneys. Similarly, long term exposure to $\mathrm{Cu}$ which is higher than normal levels can cause nausea, vomiting, stomach cramps and or diarrhea (ATSDR, 2005).Contamination of natural water bodies has emerged as a major challenge in developing and densely populated countries like Nigeria (Ezekoye,Ilusanya, Neboh, \& Orji, 2013).The study area appears to be free of copper poisoning because higher copper concentration is injurious to human health as copper aggravates gastrointestinal disorder in man as earlier recorded (Imasuen\&Egai, 2013).

The concentrations of $\mathrm{Zn}(\mathrm{mg} / \mathrm{l})$ in the study stations of $\mathrm{X}, \mathrm{Y}$ and $\mathrm{Z}$ for the months of April, May and June respectively were $0.45 \pm 0.06,0.56 \pm 0.01,0.60 \pm 0.04 ; 0.44 \pm 0.03,0.50 \pm 0.01,0.50 \pm 0.01 ; 0.40 \pm 0.03$, $0.45 \pm 0.01$ and $0.46 \pm 0.01$. The months of April, May and June recorded controls values of $0.15,0.15$ and 0.14 respectively. The observed range for $\mathrm{Zn}$ in this study was $0.44 \pm 0.04-0.54 \pm 0.04$. Thesevalues were though within the WHO permissible limits of $0.3 \mathrm{mg} / 1$, FEPA/FMENV standard of $0.5 \mathrm{mg} / \mathrm{l}$ but lower than that SON (2002) of 3.0mg/l. The concentration of $\mathrm{Zn}$ in the study station was higher than those of the control showing anthropogenic inputs of the suspected sites and activities. These concentrations were within the lower limit of the range but lower than those of the upper limit (Edori, Nwoke\&Iyama, 2016). Similarly, Iyama and Edori (2019) observed that the range of Zn was 0.034$0.086 \mathrm{mg} / \mathrm{l}$ in assessment of chemical and gross organic pollutant levels for dumpsites in Port Harcourt. This variation in the concentration of $\mathrm{Zn}$ could be linked to some external inputs. Lower values were also recorded compared to the result of this study earlier (Adesina et al., 2018; Javed\&Usmani, 2013).Agency for Toxic Substances and Disease Registry (ATSDR 2005), suggests that ingesting high levels of zinc for several months may cause anemia, damage the pancreas, and decrease levels of high-density lipoprotein (HDL) cholesterol.According to Masona, Mapfaire, Mapurazi and Makanda (2011), the study revealed that wastewater increases heavy metal concentrations in soils which also agreed with similar and earlier research work of Schmidt (1997) that toxic heavy metals, in particular $\mathrm{Cd}, \mathrm{Cu}, \mathrm{Zn}, \mathrm{Ni}$ and $\mathrm{Pb}$ are frequently present in high concentrations in wastewater.

The concentrations of $\mathrm{Cd}(\mathrm{mg} / \mathrm{l})$ in the study stations of $\mathrm{X}, \mathrm{Y}$ and $\mathrm{Z}$ for the months of April, May and June respectively were $0.20 \pm 0.01,0.18 \pm 0.00,0.15 \pm 0.02 ; 0.12 \pm 0.00,0.10 \pm 0.01,0.14 \pm 0.01 ; 0.10 \pm 0.00$, $0.08 \pm 0.01$ and $0.10 \pm 0.01$. The months of April, May and June recorded controls values of 0.015, 0.014 and 0.010 respectively. The concentration of $\mathrm{Cd}$ in the study station was higher than those of the control showing anthropogenic inputs of the suspected sites and activities. The recorded range of $\mathrm{Cd}$ in this study was $0.09 \pm 0.03-0.18 \pm 0.04$ which was higher than the permissible limits of $0.003 \mathrm{mg} / 1$ (WHO, 2006; SON, 2002). This was against the No detection (ND) level recorded by Edoriet al. (2016) in local boreholes in Rivers state. The lower the level of permissible limit the more toxic the heavy metal tolerance. That is why $\mathrm{Cd}$ is one of the most dangerous heavy metals. Adesina et al. (2018) recorded relatively lower values (mean of $0.00035 \mathrm{mg} / \mathrm{l}$ ) compared to the result of this study. This high content of $\mathrm{Cd}$ is likely from anthropogenic inputs from wastes especially due to the presence of residential homes, waste dump from discarded batteries. Cadmium (Cd) has no biological relevance and so non-essential to human development (Akpor and Muchie, 2011). This metal falls 
into one of the eight (8) heavy metals often referred to as RCRA (Resource Recovery and Conservation Act) 8 metals. This is due to their extreme toxicity even at low concentration

The concentrations of $\mathrm{Pb}(\mathrm{mg} / \mathrm{l})$ in the study stations of $\mathrm{X}, \mathrm{Y}$ and $\mathrm{Z}$ for the months of April, May and June respectively were $0.02 \pm 0.01,0.01 \pm 0.00,0.01 \pm 0.00 ; 0.01 \pm 0.00,0.01 \pm 0.00,0.01 \pm 0.00 ; 0.01 \pm 0.00$, $0.01 \pm 0.00$ and $0.01 \pm 0.00$. The months of April, May and June recorded controls values of $<0.01$, $<0.01$ and $<0.01$ respectively. The concentration of $\mathrm{Pb}$ in the study station was higher than those of the control showing anthropogenic inputs of the suspected sites and activities. The recorded range of $\mathrm{Cd}$ in this study was $0.01 \pm 0.00-0.02 \pm 0.01$ which was within the permissible limit of $0.01 \mathrm{mg} / 1$ (WHO, 2006; SON, 2002; DPR, 1991).Only station X in April recorded slight increase of $0.02 \mathrm{mg} / \mathrm{l}$ which meant that there must be an external body responsible or the soil natural content. Adesina et al. (2018) recorded relatively lower concentrations in the study of abattoir wastes in Ogun state, Nigeria but higher concentrations by Imasuen and Egai (2013) of range $<0.001-0.48 \mathrm{mg} / \mathrm{l}$ for concentration and environmental implication of heavy metals in surface water in AguobiriCommunity, Southern Ijaw Local Government Area, Bayelsa State, Nigeria. Though this concentration fell within the WHO/FMENV standard of range 0.01-0.05, there is the ardent need to be cautious due to the gradual presence of $\mathrm{Pb}$ around the study site. The presence of $\mathrm{Pb}$ is most likely due to anthropogenic input from the cement factory and the related activities of heavy duty trucks. Iyama and Edori (2019) observed from dumpsite in Port Harcourt a $0.00 \mathrm{mg} / \mathrm{l}$ level showing that there is gradual increase around this study stations as the progresses. This is a dangerous trend and threat to ground water and hence human. Lead $(\mathrm{Pb})$ has no biological role and hence non-essential (Akpor\&Muchie, 2010). Figures 1 and 2 give the temporal and spatial trends of the heavy metals for the study respectively.

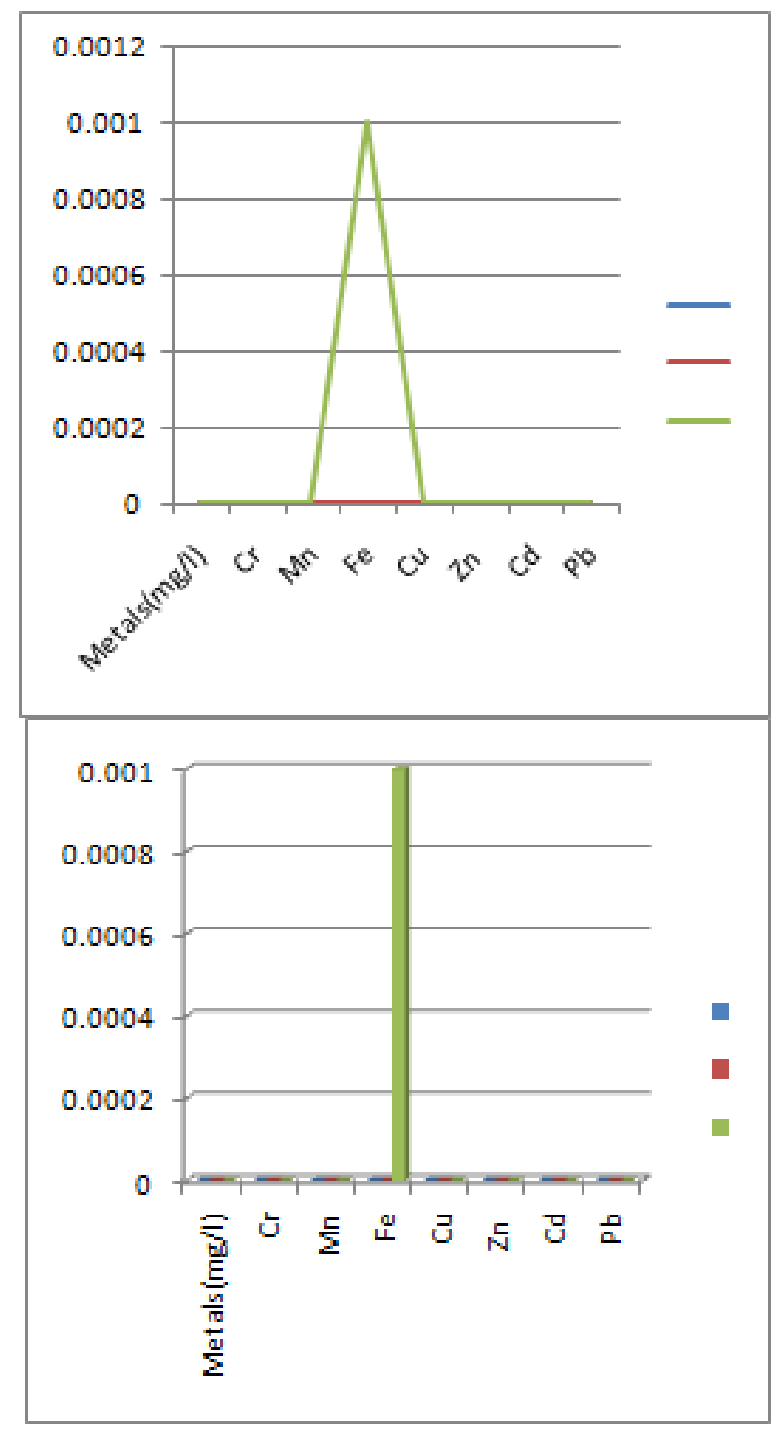

Figure1. Temporal Mean Variation of Heavy Metals in the Study 


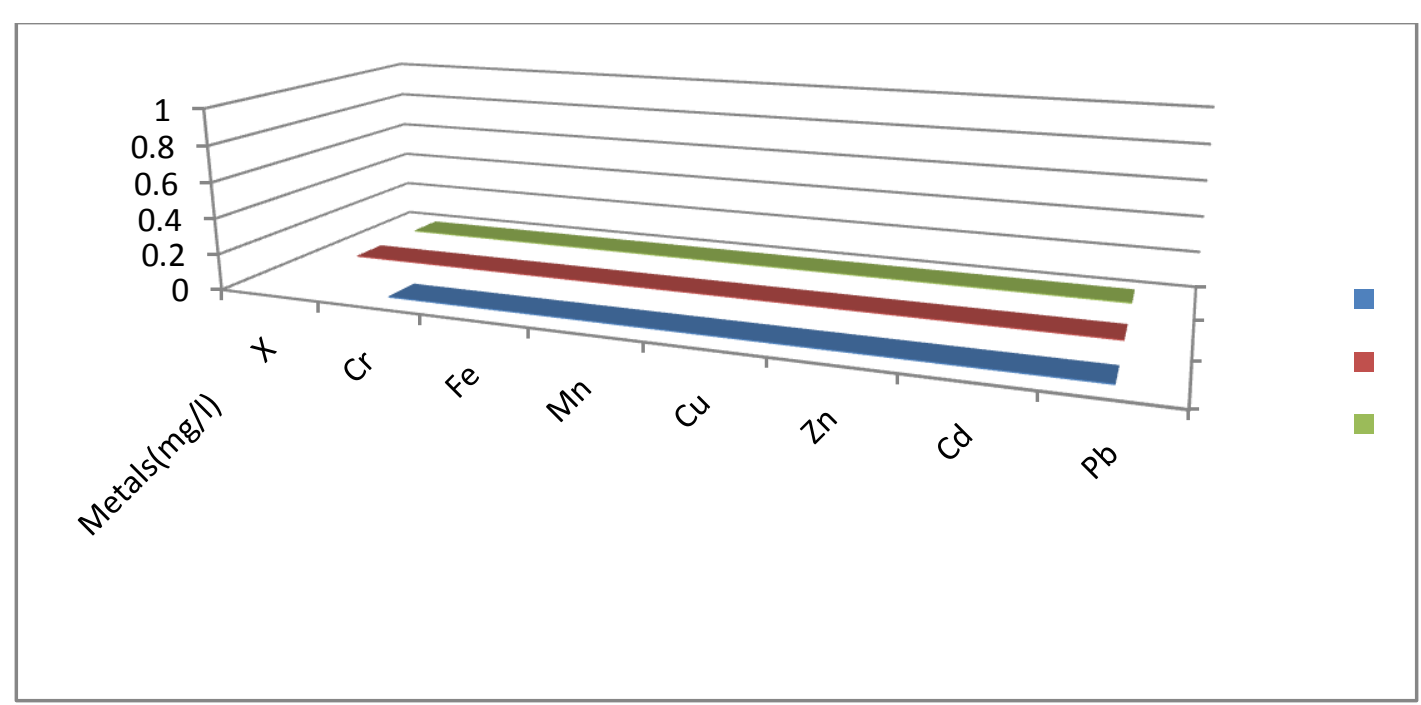

Figure2. Spatial Mean Trend for Heavy Metals

A one way ANOVA was used to compare the relationship of the three months (April, May and June) and the three stations $(\mathrm{X}, \mathrm{Y}, \mathrm{Z})$. Temporal and spatial variation showed result not significant $(\mathrm{p}<0.05)$ as F-ratio were 0.1224 and 0.0121 respectively. Similarly, t-test was used to compare the mean values from the control values $(\mathrm{p} \leq 0.05)$. The result showed that for April and June there were statistical significance unlike in May compared to the control station results.

\section{CONCLUSION}

This research showed that there is gradual input of human interference especially from the impact of subsidiary activities from the cement factory and the abandoned waste dump. The study also revealed that $\mathrm{Cr}, \mathrm{Mn}, \mathrm{Zn}, \mathrm{Cd}$ exceeded the regulatory standards but $\mathrm{Pb}$ presence is a potential threat. There was low concentration of $\mathrm{Fe}$ but $\mathrm{Cu}$ is gradually building up as its concentration is very close to the WHO limits even though below that of FEPA/ FMENV and SON. The potential variation of heavy metals in the study was of the trend, $\mathrm{Fe}<\mathrm{Pb}<\mathrm{Cd}<\mathrm{Cr}<\mathrm{Mn}<\mathrm{Cu}<\mathrm{Zn}$. The concentrations of all the heavy metals were larger than their respective control values showing the impact of external factors which must be checked.

\section{REFERENCES}

[1] Adesina, A.O.,Ogunyebi, A.l., Fingesi, T.S. \&Oludoye, O.O. (2018). Assessment of Kara Abattoir Effluent on the Water Quality of Ogun River, Nigeria. J. Appl. Sci. Environ. Manage., 22 (9) 1465 -1470. https://www.ajol.info/index.php/jasemhttp://ww.bioline.org. br /ja

[2] A dictionary of chemistry (2000). Oxford university press. Oxford reference [Online], Oxford University Press.

[3] Ahmed, M.J.K. \&Ahmaruzzaman, M. (2016). A review on potential usage of industrial waste materials for binding heavy metal ions from aqueous solutions. J. Water Process Eng., 10:39-47.

[4] Akpor, O. \&Muchie, M. (2010). Remediation of heavy metals in drinking water and wastewater treatment systems: processes and applications. Int. J. Phys. Sci., 5 (12):1807-1817.

[5] Araujo, C. S. T., Carvalho, D. C., Rezende, H. C., Almeida, I. L. S., Coelho, L. M., Coelho, N. M. M., Marques, T. L., \& Alves, V. N. (2013). Bioremediation of Waters Contaminated with Heavy Metals Using Moringa oleifera Seeds as Biosorbent. In Y. Patil (Ed.), AppliedBioremediation-Active and Passive Approaches (pp. 249-255). InTech. https://doi.org/10.5772/56157

[6] ATSDR (2005). Agency for Toxic Substances and Disease Registry. Clifton Road, Atlanta: Division of Toxicology.

[7] Bhaskar, C.V., Kumar, K. \&Nagendrappa, G. (2010). "Assessment of Heavy Metals in Water Samples of Certain Locations Situated Around Tumkur, Karnataka, India". Journal of Chemistry, vol. 7, Article ID 415150, 4 pages, 2010. https://doi.org/10.1155/2010/415150

[8] Bhattacharya, A.K. \& Bolaji, G.A. (2010). Fluid Flow interactions in Ogun River, Nigeria. International Journal of Recent Research and Applied Studies, 2(2): 173-180.

[9] Buchauer, M.J. (1973). "Contamination of soil and vegetation near a zinc smelter by zinc, cadmium, copper, and lead". Environmental Science \& Technology, 7(2):131-135. 
[10] Cai, Q.Y., Mob, C.H., Wu, Q.T., Zenga Q.Y.\&Katsoyiannis, A. (2007).Concentration and speciation of heavy metalsin six different sewage sludge-composts. Journal of Hazardous Materials, 147, 1063-1072.

[11] Chowdhury, S.,Mazumder, M.J., Al-Attas, O. \& Husain, T. (2016). Heavy metals in drinking water: occurrences, implications, and future needs in developing countries .Sci. Total Environ., 569:476-488.

[12] Chronopoulos J, Haidouti C, Chronopoulou A, Massas I. (1997). Variations in plant and soil lead and cadmium content in urban parks in Athens, Greece. Sci Total Environ. 196:91-8.

[13] Chukwu , O., Mustapha, H.I. \& Abdul Gafar , H.B. (2008). The Effect of Minna Abattoir Waste on Surface Water Quality II. Environmental Research Journal, 2: 339-342. https://medwelljournals.com/abstract/?doi=erj.2008.339.342.

[14] Demirezen, D. \& Aksoy, A. (2006). "Heavy metal levels in vegetables in Turkey are within safe limits for $\mathrm{Cu}, \mathrm{Zn}, \mathrm{Ni}$ and exceeded for Cd and Pb," Journal of Food Quality, 29 (3): 252- 265.

[15] DPR (1991). Department of Petroleum Resources, Environmental guidelines and Standards for the Petroleum Industry in Nigeria (EGASPIN).

[16] Duruibe, J.O., Ogwuegbu, M.O.C.\&Egwurugwu, J.N.(2007). Heavy metal pollution and human biotoxic effects. International Journal of physical sciences, 2(5):112-118.

[17] Edori, O.S., Nwoke, I.B. \&Iyama, W.A. (2016). Heavy metals and physicochemical parameter of selected borehole water from Umuechem, Etche Local government Area, Rivers state, Nigeria. International journal of chemistry and chemical engineering, 6 (1):45-57.

[18] Ezekoye, C.C., Ilusanya, O.A., Neboh, H.A. \& Orji, F.A. (2013). Assessment of Ijebu-Igbo Abattoir Effluent and its impact on the ecology of the receiving soil and river. Journal of Environmental Science, Toxicology and Food Technology 7(5):61-67.

[19] FEPA (1991). Federal Environmental Protection Agency. Guidelines and Standards for Environmental Pollution Control in Nigeria, 350p.

[20] Fergusson, J.E. (1990). The Heavy Elements: Chemistry, Environmental Impact and Health Effects, Pergamin Press, Oxford, UK.

[21] Goyer, R.A. (1997). "Toxic and essential metal interactions". Annual Review of Nutrition, 17: 37-50.

[22] Imasuen, I. \&Egai, A.O. (2013). Concentration and Environmental Implication of Heavy Metals in Surface Water in Aguobiri Community, Southern Ijaw Local Government Area, Bayelsa State, Nigeria. J. Appl. Sci. Environ. Manage., 17 (4) 467-472.

[23] Iyama, W.A., Eugene-Nwala, O.\&Igoni, I. (2017). Assessment of the Various Physicochemical Parameters and Heavy Metals Pollution Potentials of Ekerikana Water body, Rivers State, Rivers State, Nigeria. International Journal of Chemistry, Pharmacy and Technology, 2(43): 162-168.

[24] Iyama, W.A. \&Edori, O.S. (2019). Determination of Chemical and Gross Organic Pollutant Levels in Leachates from Approved Waste Dumpsites, Port Harcourt Metropolis, Rivers State, Nigeria. Journal of Global Ecology and Environment, 9(1): 29-38.

[25] Jabeen, F., Aslam, A. \& Salman, M. (2018). Heavy metals toxicity and associated health risks in vegetables grown under soil irrigated with sewage water. Univ. J. Agric. Res., 6 (5): 173- 180

[26] Järup, L. (2003). Hazards of heavy metal contamination. Br Med Bull.,68 (1):167-182.

[27] Javed, M. \&Usmani, N. (2013).Assessment of heavy metal (Cu, Ni, Fe, Co, Mn, Cr, Zn) pollution in effluent dominated rivulet water and their effect on glycogen metabolism and histology of Mastacembelusarmatus. Springerplus, 2(390):1-13.

[28] Kar, D., Sur, P., Mandal, S. K., Saha, T.\&Kole, R. K.(2008). Assessment of heavy metal pollution in surface water. Int J Environ Sci Tech., 5(1), 119-124.

[29] Khan, S., Cao, Q., Zheng, Y.M., Huang Y.Z. \& Zhu Y.G.(2008). Health risks of heavy metals in contaminated soils and food crops irrigated with wastewater in Beijing, China. Environmental Pollution, 152, 686-692.

[30] Koller, M. \& Saleh, H.M. (2018). Introductory Chapter: Introducing Heavy Metals, Heavy Metals, Hosam El-Din M. Saleh and Refaat F. Aglan, IntechOpen,

[31] DOI: 10.5772/intechopen.74783. Available from: https://www.intechopen.com/books/heavymetals/introductory-chapter-introducing- heavy-metals.

[32] Ma, Q.Y.,Traina, S.J., Logan, T.J. \&Ryan, J.A.(1994). "Effects of Aqueous Al, Cd, Cu, Fe(II), Ni, and Zn on Pb Immobilization by Hydroxyapatite," Environmental Science \& $\quad$ Technology, 28, (7):12191228.

[33] Mahdavi, M., Amin, M.M., Mahvi, A.H., Pourzamani, H. \& Ebrahimi, A. (2018). Metals, heavy metals and microorganism removal from spent filter backwash water by hybrid coagulation-UF processes. J. Water Reuse Desalination, 8 (2):225-233. 
[34] Masona, C., Mapfaire, L., Mapurazi, S. \&Makanda, R. (2011). Assessment of Heavy Metal Accumulation in Wastewater Irrigated Soil and Uptake by Maize Plants (Zea Mays L) at Firle Farm in Harare. Journal of Sustainable Development, 4 (6); 132-137.

[35] McBride, M.B. (2003). "Toxic metals in sewage sludge-amended soils: Has promotion of beneficial use discounted the risks?" Advances in Environmental Research, 8(1):5-19.

[36] McIntyre, T.(2003). Phytoremediation of heavy metals from soils. Adv BiochemEng Biotechnol., $\quad$ 78:97123.

[37] Midrar-Ul-Haq, R.A.,Khattak, H.K., Puno, M.S., Saif, K.S. \&Memon.,(2005). "Surface and ground water contamination in NWFP and Sindh provinces with respect to trace elements," International Journal of Agriculture and Biology, 7(2):214-217.

[38] Mileusnić, M.,Mapani, B.S., Kamona, F.A., Ružičić, S., Mapaure I., Chimwamurombe, P.M., (2014). Assessment of agricultural soil contamination by potentially toxic metals dispersed from improperly disposed tailings, Kombat mine, Namibia, Journal of Geochemical ExplorationVolume 144 , pp 409-420

[39] Msaky, J.J. \& R. Calvet, R. (1990). “Adsorption behavior of copper and zinc in soils: Influence of pH on adsorption characteristics," Soil Science, 150(2):513-522.

[40] Neklyudov, A.D., Fedotov, G.N. \&Ivankin,A.N.(2008). Intensification of Composting Processes by Aerobic Microorganisms: A Review. Applied Biochemistry and Microbiology, 44, (1):6-18.

[41] Njuguna, S.M., Makokha, V.A., Yan, X., Gituru, R.W., Wang, Q. \& Wang, J. (2019). Health risk assessment by consumption of vegetables irrigated with reclaimed waste water: a case study in Thika (Kenya). J. Environ. Manage., 231:576-581.

[42] Noreen, M., Shahid, M., Iqbal, M. \& Nisar, J. (2017). Measurement of cytotoxicity and heavy metal load in drains water receiving textile effluents and drinking water in vicinity of drains. Measurement, 109: 8899.

[43] Rajappa, B., Manjappa, S. \&Puttaiah, E.T. (2010). Monitoring of heavy metal concentration in groundwater of HakinakaTaluk, India. Contemporary Engineering Sciences, 3(4):183- 190.

[44] Raju, O.V.S., Prasad, P.M.N, Varalakshmi, V. \& Reddy, Y.V.R. (2014). Determination of Heavy Metals In Ground Water By Icp-Oes In Selected Coastal Area Of Spsr Nellore District, Andhra Pradesh,India. International Journal of Innovative Research in Science, Engineering and Technology, 3 (2): 2319-8753.

[45] Ramesh, P. \&Damodhram, T. (2016). Determination of Heavy Metals in Industrial Waste Waters of Tirupati Region, Andhra Pradesh. International Journal of Science and Research (IJSR), 5(5): 24522455.

[46] Rao, C.R.M.\&Reddi, G.S.(2000). Platinum group metals (PGM); occurrence, use and recent trends in their determination.TrACTrends in Analytical Chemistry, $19 \quad$ (9):565-586 http://dx.doi.org/10.5772/intechopen.747837.

[47] Santos, I.R., Silva-Filho, E.V., Schaefer, C.E.G.R., Albuquerque-Filho, M. R. \& Campos, L.S. (2005). "Heavy metal contamination in coastal sediments and soils near the Brazilian Antarctic Station, King George Island," Marine Pollution Bulletin,50 (2): 185-194.

[48] Schmidt, J. P. (1997). Understanding phytotoxicity threshold for trace elements in land-applied sewage sludge. Journal of Environment Quality, 26, 4-10. http://dx.doi.org/ 10.2134/jeq1997.00472425002600010002x.

[49] Singh, O.V., Labana S., Pandey, G., Budhiraja, R. \& Jain, R.K. (2003). Phytoremediation: an overview of metallic ion decontamination from soil. Appl. Microbiol. Biotechnol. $\quad 61(5): 405412$.

[50] Singh, M.R.(2007). Impurities-heavy metals: IR prespective. [Last cited on 2009 Aug 10]. http://www.usp.org/pdf/EN/meetings/asMeetingIndia/2008Session4track1.pdf.

[51] Singh, J. \&Kalamdhad, A.S. (2011). Effects of Heavy Metals on Soil, Plants, Human Health and Aquatic Life. International Journal of Research in Chemistry and Environment, 1(2): 15-21.

[52] Singh,R., Gautam, N., Mishra,A.\& Gupta, R.(2011).Heavy metals and living systems: An overview. Indian J Pharmacol. 43(3): 246-253.doi: 10.4103/0253- 7613.81505.

[53] Sobha K., Poornima A., Harini P. \&Veeraiah K.(2007). A study on biochemical changes in the fresh water fish, catlacatla (hamilton) exposed to the heavy metal toxicant cadmium chloride. Kathmandu University Journal of Science, Engineering and Technology, 1 (4):1-11.

[54] SON (2002). Nigerian Standards for Drinking Water Quality, Revised edition 2007.

[55] Tariq, M., Ali, M. \& Shah, Z. (2006). "Characteristics of industrial effluents and their possible impacts on quality of underground water," Soil Environment, 25(1): 64-69. 
[56] Tchounwou, P. B., Yedjou, C. G., Patlolla, A. K., \& Sutton, D. J. (2012). Heavy metal toxicity and the environment. Experienti Supplementum (2012), 101, 133-164. https://doi.org/10 .1007/ 978-3-7643-83404_6

[57] Terrumun, K.K \& Oliver, T.I. (2015). Assessment of the Impact of Abattoir Effluent on the Water Quality of River Kaduna, Nigeria. World J. Environ. Engineer, 3(3): 87-94.

[58] Türkdoğan, M.K., Kilicel,F., Kara, K., Tuncer, I. \&Uygan, I. (2003). Heavy metals in soil, vegetables and fruits in the endemic upper gastrointestinal cancer region of Turkey.Environ. Toxicol. Pharmacol., 13 (3):175-179.

[59] Voutsa, D., Grimanis, A. \& Samara, C. (1996). "Trace elements in vegetables grown in an industrial area in relation to soil and air particulate matter," Environmental Pollution, 94(3):325-335.

[60] WHO (2006). World Health Organization, Guidelines for drinking water quality, Recommendation Geneva, Switzerland.

[61] Xiang Zeng, Xijin Xu, Qilin Qin, Kai Ye, Weidong Wu \& Xia HuoZenglu, X. (2019). Soil environmental capacity of China. Earthquake Publishing, China ,41, 309-321.https://doi.org/10.1007/s10653-018-0114-Z

[62] Zorpas,A.A., Vassilis, I., Loizidou, M. \&Grigoropoulou, H.(2002). Particle Size Effects on Uptake of Heavy Metals from Sewage Sludge Compost Using Natural Zeolite Clinoptilolite. Journal of Colloid and Interface Science, 250:1- 4.

Citation: Edori, OnisogenSimeo ,et.al.," Assessment of Heavy Metal Content of Drain Water with in Cement Production Environment in Port Harcourt, Nigeria ", International Journal of Research in Environmental Science (IJRES), vol. 6, no. 4, pp. 51-62, 2020. Available: DOI: http://dx.doi.org/10.20431 /24549444.0604005

Copyright: (C) 2020 Authors. This is an open-access article distributed under the terms of the Creative Commons Attribution License, which permits unrestricted use, distribution, and reproduction in any medium, provided the original author and source are credited. 